\title{
Aplikasi Jaringan Saraf Tiruan Backpropagation untuk Penyebaran Penyakit Demam Berdarah Dengue (DBD) di Kota Ambon
}

\author{
Yopi Andry Lesnussa, Lexy Janzen Sinay, Mus Rika Idah \\ Jurusan Matematika-Universitas Pattimura \\ yopi_a_lesnussa@yahoo.com, lexyjz@gmail.com, imusrika@gmail.com
}

\begin{abstract}
Abstrak
Jaringan Syaraf Tiruan adalah pemprosesan sistem informasi pada karakteristik tertentu yang merupakan representatif buatan berdasarkan jaringan syaraf manusia. Jaringan Syaraf Tiruan dapat diaplikasikan pada berbagai bidang dalam kehidupan manusia, salah satunya bidang kesehatan. Dalam penelitian ini, Jaringan Syaraf Tiruan digunakan untuk penyebaran penyakit DBD dengan menggunakan metode backpropagation. Data yang digunakan dalam penelitian ini sebanyak 82 data, dengan 62 data sebagai data pelatihan dan 20 data sebagai data pengujian. Data suhu rata-rata, curah hujan, jumlah hari hujan, kepadatan penduduk dan angka bebas jentik (ABJ) merupakan data masukan sedangkan yang menjadi target atau keluaran adalah data kasus DBD di Kota Ambon. Dari hasil penelitian, diperoleh arsitektur jaringan terbaik dari satu hidden layer dengan jumlah neuron sebanyak 25 neuron dan algoritma pelatihan terbaik yaitu dengan menggunakan learning rate sebesar 0,4 dengan MSE 0,0099. Dengan demikian, dapat disimpulkan bahwa aplikasi Jaringan Saraf Tiruan metode backpropagation untuk penyebaran penyakit DBD di Kota Ambon memiliki tingkat keakuratan yang tinggi yaitu sebesar $90 \%$. Hal ini berarti bahwa, factor cuaca, suhu, kepadatan penduduk dan angka bebas jentik turut mempengaruhi penyebaran penyakit DBD di Kota Ambon.

Kata kunci: Jaringan Syaraf Tiruan; Backpropagation; DBD
\end{abstract}

\begin{abstract}
The Artificial Neural Networks is a process of informational system on certain traits which are artificial representatives of the human neural networks. The Artificial neural networks will be applied on many fields of human life. One of them is the fields of health. In this research, the artificial neural networks is used to diagnose internal diseases using the Backpropagation. The number of data used in this research is 82 data, 62 of them is used as training data and 20 the remaining as testing data. The average temperature, rainfall, number of rainy days, the population density, and the percentage of larvae-free number be input data while which become a output data is DBD case in Ambon city. From the results obtained by training the best network architecture is the number one hidden layer with the number of neurons obtained a total of 25 neurons and the best training algorithm using a variable learning rate 0.4 the end of the training MSE 0.0099. Thus, it can be concluded that applied of Artificial Neural Network for the disease spread of DBD in Ambon City had high accurate level that is 90\%. This means, weather factors, temperature, population density and free number of larvae also affect the spread of dengue disease in Ambon City.

Keywords : Artificial Neural Networks; Backpropagation; DBD
\end{abstract}




\section{Pendahuluan}

Penyakit Demam Berdarah Dengue (DBD) adalah penyakit yang disebabkan oleh virus dengue yang masuk melalui peredaran darah manusia melalui gigitan nyamuk dari genus Aedes, misalnya Aedes aegepty atau Aedes albopictus. Penyakit DBD dapat muncul sepanjang tahun dan dapat menyerang seluruh kelompok umur. Penyakit ini berkaitan dengan kondisi lingkungan dan perilaku masyarakat (Dinkes Prov. Maluku, 2015).

Pada tahun 2014, sampai pertengahan bulan Desember tercatat penderita DBD di 34 provinsi di Indonesia sebanyak 71.668 orang, dan 641 diantaranya meninggal dunia. Angka tersebut lebih rendah dibandingkan tahun sebelumnya, yakni tahun 2013 dengan jumlah penderita sebanyak 112.511 orang dan jumlah kasus meninggal sebanyak 871 penderita (Kemenkes RI, 2015). Di Provinsi Maluku, pada tahun 2014 jumlah penderita DBD yang dilaporkan dari 11 kabupaten kota sebanyak 17 kasus, dengan jumlah kematian yaitu 3 orang yang terdapat di kabupaten Maluku Tenggara 2 orang dan kota Ambon 1 orang. Angka kesakitan (Incidend Rate) sebesar 1,0 per 100.000 penduduk dan angka kematian (Case Fatality Rate) sebesar 17,6\%. Tahun 2013, jumlah penderita DBD yang dilaporkan sebanyak 43 kasus dengan jumlah kematian 3 orang dengan IR sebesar 2,64 per 100.000 penduduk dan CFR sebesar 6,98

Pengenalan ilmu matematika dalam ilmu kesehatan sangat membantu dalam menyelesaikan masalah yang kompleks terkait dengan pengolahan data-data dalam mengenali pola dari suatu penyakit yang akan datang. Oleh sebab itu diperlukan suatu metode yang dapat digunakan untuk mempelajari output dari data-data yang telah diinputkan dalam suatu sistem. Salah satu metode yang dapat digunakan untuk mengidentifikasi data sebagai pengenalan pola suatu kejadian yang akan datang adalah Jaringan Syaraf Tiruan (Artificial Neural Network). Jaringan syaraf tiruan merupakan salah satu sistem pemrosesan yang dirancang dan dilatih untuk memiliki kemampuan seperti yang dimiliki oleh manusia dalam menyelesaikan persoalan yang rumit dengan melakukan proses belajar melalui perubahan bobot. Jaringan syaraf mensimulasi struktur proses-proses otak (fungsi syaraf biologis) dan kemudian membawanya kepada perangkat lunak kelas baru yang dapat mengenali pola-pola yang kompleks serta belajar dari pengalaman-pengalaman masa lalu. Perkembangan teknologi pengenalan pola saat ini banyak menciptakan aplikasi-aplikasi baru sesuai dengan perkembangan zaman. Oleh sebab itu pada penelitian ini menggunakan aplikasi JST dalam bidang kesehatan untuk mengetahui penyebaran dari penyakit DBD yang terjadi di suatu wilayah. . .

\section{Tinjauan Pustaka}

Pada panduan ini akan dijelaskan tentang penulisan heading. Jika heading anda melebihi satu, gunakan level kedua heading seperti di bawah ini.

2.1. Definisi Jaringan Syaraf Tiruan. Jaringan Syaraf Tiruan (JST) merupakan salah satu representasi buatan dari otak manusia yang selalu mencoba untuk mensimulasikan proses pembelajaran otak manusia tersebut (Andrijasa, 2010). JST tercipta sebagai suatu generalisasi model matematik dari pemahaman manusia (human cognition) yang didasarkan atas asumsi pemrosesan informasi terjadi pada elemen sederhana yang disebut neuron, isyarat mengalir diantara sel syaraf melalui suatu sambungan penghubung, setiap sambungan penghubung memiliki bobot yang bersesuaian, dan setiap sel syaraf akan merupakan fungsi aktivasi terhadap isyarat hasil penjumlahan berbobot yang masuk kepadanya untuk menentukan isyarat keluarannya (Jumarwanto, 2009). JST ditentukan oleh 3 hal :

(1) Pola hubungan antar neuron (disebut arsitektur jaringan)

(2) Metode untuk menentukan bobot penghubung

(3) Fungsi aktivasi. Sebagai contoh, perhatikan neuron Y pada Gambar 2.3

Y menerima input dari neuron $x_{1}, x_{2}, x_{3}$ dengan bobot hubungan masing- masing adalah $w_{1}, w_{2}, w_{3}$. Ketiga impuls neuron yang ada dijumlahkan yaitu net $=x_{1} w_{1}+x_{2} w_{2}+x_{3} w_{3}$. 


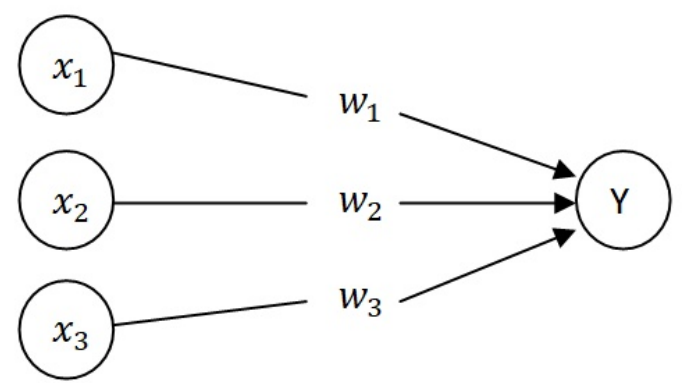

GAmBAR 1. Fungsi Aktivasi

Besarnya impuls yang diterima oleh $Y$ mengikuti fungsi aktivasi $y=f(n e t)$. Apabila nilai fungsi aktivasi cukup kuat, maka sinyal akan diteruskan. Nilai fungsi aktivasi (keluaran model jaringan) juga dapat dipakai sebagai dasar untuk merubah bobot

2.2. Konsep Dasar Jaringan Syaraf Tiruan. Setiap pola-pola informasi input dan output yang diberikan kedalam JST diproses dalam neuron. Neuron-neuron tersebut terkumpul di dalam lapisan-lapisan yang disebut neuron layers. Lapisan-lapisan penyusun JST tersebut dapat dibagi menjadi 3, yaitu :

(1) Lapisan input, unit-unit di dalam lapisan input disebut unit-unit input. Unit-unit input tersebut menerima pola data dari luar yang menggambarkan suatu permasalahan.

(2) Lapisan tersembunyi, unit-unit di dalam lapisan tersembunyi disebut unit-unit tersembunyi. Di mana outputnya tidak dapat secara langsung diamati.

(3) Lapisan Output, unit-unit di dalam lapisan output disebut unit-unit output. Output dari lapisan ini merupakan solusi JST terhadap suatu permasalahan.

2.3. Arsitektur Jaringan Syaraf Tiruan. JST memiliki beberapa arsitektur jaringan yang sering digunakan dalam berbagai aplikasi. Arsitektur JST tersebut, antara lain (Sukma Puspitorini, 2012) :

(1) Jaringan Lapisan Tunggal (Single Layer Network)

Jaringan dengan lapisan tunggal terdiri dari 1 lapisan input dan 1 lapisan output. Setiap neuron yang terdapat di dalam lapisan input selalu terhubung dengan setiap neuron yang terdapat pada lapisan output. Jaringan ini hanya menerima input kemudian secara langsung akan mengolahnya menjadi output tanpa harus melalui lapisan tersembunyi.

(2) Jaringan Banyak Lapisan (Multilayer Net)

Jaringan dengan lapisan jamak memiliki ciri khas tertentu yaitu memiliki 3 jenis lapisan yakni lapisan input, lapisan output, dan lapisan tersembunyi. Jaringan dengan banyak lapisan ini dapat menyelesaikan permasalahan yang lebih kompleks dibandingkan jaringan dengan lapisan tunggal. Namun, proses pelatihan sering membutuhkan waktu yang cenderung lama.

(3) Jaringan Lapisan Kompetitif (Competitive Layer)

Pada jaringan ini sekumpulan neuron bersaing untuk mendapatkan hak menjadi aktif. Contoh algoritma yang menggunakan jaringan ini adalah LVQ.

2.4. Fungsi Aktivasi Backpropagation. Dalam backpropagation, fungsi aktivasi yang dipakai harus memenuhi beberapa syarat yaitu: kontinu, terdiferensial dengan mudah dan merupakan fungsi yang tidak turun. Salah satu fungsi yang memenuhi ketiga syarat tersebut 


\section{Lapisan Input}

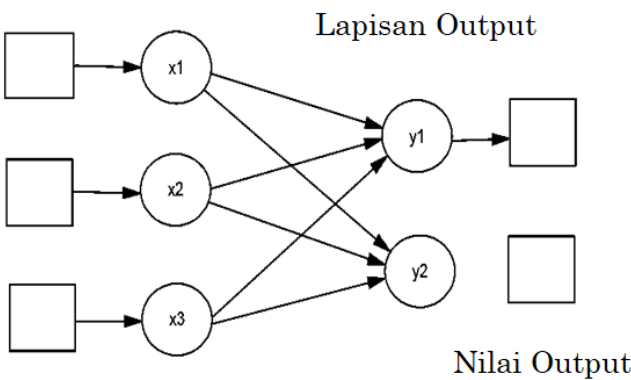

Nilai Input

Gambar 2. Arsitektur Lapisan Tunggal

Lapisan Input

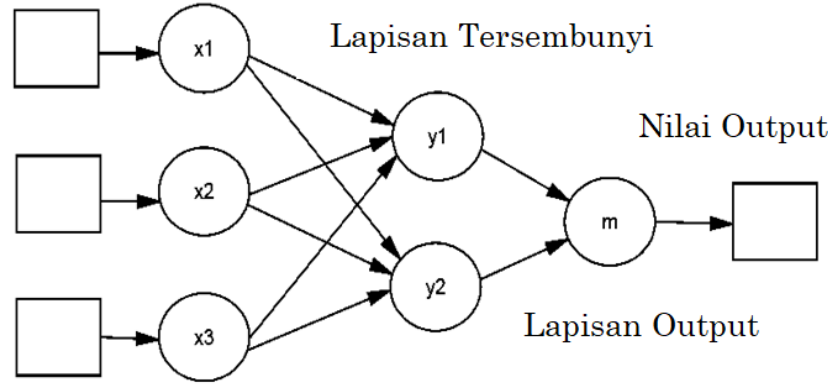

Nilai Input

Gambar 3. Arsitektur Banyak Lapisan

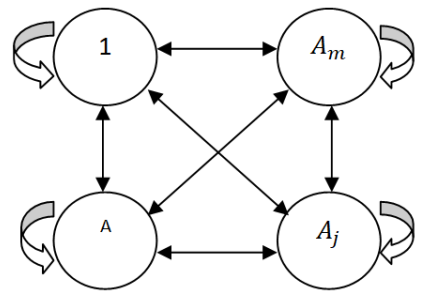

Gambar 4. Arsitektur Lapisan Kompetitif

sehingga sering dipakai adalah fungsi sigmoid biner yang memiliki range $(0,1)$. Diberikan $f(x)=\frac{1}{\left(1+e^{(-x))}\right.}$ dengan turunan $f^{\prime}(x)=f(x)(1-f(x))$.

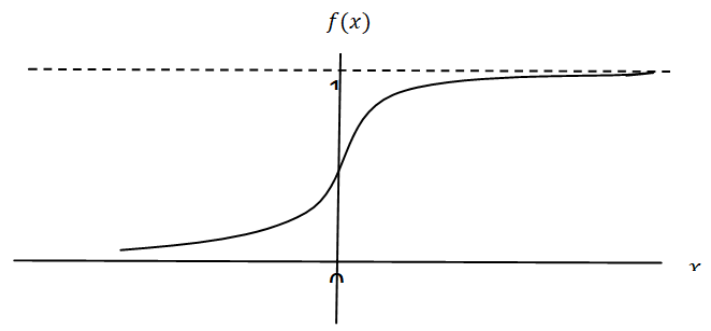

Gambar 5. Fungsi Aktivasi Sigmoid Biner 
Fungsi lain yang sering dipakai adalah fungsi sigmoid bipolar yang bentuk fungsinya mirip dengan fungsi sigmoid biner, tapi dengan range $(-1,1)$. Diberikan $f(x)=\frac{2}{\left(1+e^{(-x)}\right)}-1$ dengan turunan $f^{\prime}(x)=\frac{(1+f(x))(1-f(x))}{2}$.

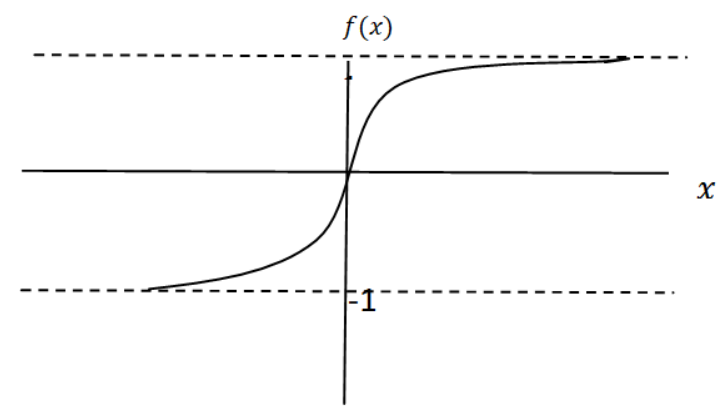

Gambar 6. Fungsi Aktivasi Sigmoid Bipolar

Fungsi sigmoid memiliki nilai maksimum $=1$. Maka untuk pola yang targetnya lebih dari 1, pola masukan dan keluaran harus terlebih dahulu di transformasi sehingga semua polanya memiliki range yang sama seperti fungsi sigmoid yang dipakai. Alternatif lain adalah menggunakan fungsi aktivasi sigmoid hanya pada lapisan yang bukan lapisan keluaran. Pada lapisan keluaran, fungsi aktivasi yang dipakai adalah fungsi identitas: $f(x)=x$.

2.5. Pelatihan Standar Backpropagation. Pelatihan backpropagation meliputi 3 Tahap yaitu tahap maju, propagasi mundur, dan perubahan bobot. Algoritma pelatihan untuk jaringan dengan satu lapisan tersembunyi (dengan fungsi aktivasi sigmoid biner) adalah sebagai berikut :

Langkah 0 : Inisialisasi semua bobot dengan bilangan acak kecil

Langkah 1 : Jika kondisi penghentian belum terpenuhi, lakukan langkah 2-8

Langkah 2 : Untuk setiap pasang data pelatihan, lakukan langkah 3-8

\section{Tahap I : Propagasi Maju}

Langkah 3 : Tiap unit masukan menerima sinyal dan meneruskannya ke unit tersembunyi di atasnya

Langkah 4 : hitung semua keluaran di unit tersembunyi $z_{j}(j=1,2,, p)$

$$
\begin{gathered}
z_{\_} n e t_{j}=v_{j} o+\sum_{i=1}^{n} x_{i} v_{j i} \\
z_{j}=f\left(z \_n e t_{j}\right)=\frac{1}{1+e^{-z_{-} n e t_{j}}}
\end{gathered}
$$

Langkah 5 : Hitung semua keluaran jaringan di unit $y_{k}(k=1,2, m)$

$$
\begin{gathered}
y_{-} \text {net }_{k}=w_{k} o+\sum_{j=1}^{p} z_{j} w_{k j} \\
y_{k}=f\left(y \_n e t_{k}\right)=\frac{1}{1+e^{-y_{-} \text {net }_{k}}}
\end{gathered}
$$

Tahap II : Propagasi mundur

Langkah 6 : Hitung faktor unit keluaran berdasarkan eror di setiap unit keluaran $y_{k}(k=$ $1,2,, m)$

$$
\delta_{k}=\left(t_{k}-y_{k}\right) f^{\prime}\left(y_{-} n e t_{k}\right)=\left(t_{k}-y_{k}\right) y_{k}\left(1-y_{k}\right)
$$


$\delta_{k}$ merupakan unit eror yang akan dipakai dalam perubahan bobot lapisan di bawahnya (langkah 7)

Hitung suku perubahan bobot $w_{k j}$ (yang akan dipakai nanti untuk merubah bobot $w_{k j}$ ) dengan laju percepatan $\alpha$

$$
\Delta w_{k j}=\alpha \delta_{k} z_{j} \quad ; k=1,2, m ; j=0,1,2,, p
$$

Langkah 7 : Hitung faktor $\delta$ unit tersembunyi berdasarkan eror di setiap unit tersembunyi $z_{j}(j=1,2,, p)$

$$
\delta \_n e t_{j}=\sum_{k=1}^{m} \delta_{j} w_{k j}
$$

Faktor $\delta$ unit tersembunyi :

$$
\delta_{j}=\delta_{\_} \text {net }_{j} f^{\prime}\left(z_{-} n e t_{j}\right)=\delta_{-} \text {et }_{j} z_{j}\left(1-z_{j}\right)
$$

Hitung suku perubahan bobot $v_{j i}$ ( yang akan dipakai nanti untuk merubah bobot $v_{j i}$ )

$$
\Delta v_{j i}=\alpha \delta_{j} x_{i} \quad ; j=1,2,, p ; i=0,1,2, n
$$

\section{Tahap III : Perubahan bobot}

Langkah 8 : Hitung semua perubahan bobot Perubahan bobot garis yang menuju ke unit keluaran :

$$
w_{k j}(\text { baru })=w_{k j}(\text { lama })+\Delta w_{k j}(k=1,2,, m ; j=0,1,2,, p)
$$

Perubahan bobot garis yang menuju ke unit tersembunyi :

$$
v_{j i}(\text { baru })=v_{j i}(\text { lama })+\Delta v_{j i}(j=1,2,, p ; i=0,1,2, n)
$$

Setelah pelatihan selesai dilakukan, jaringan dapat dipakai untuk pengenalan pola. Dalam hal ini, hanya propagasi maju ( langkah 4 dan 5) saja yang dipakai untuk menentukan keluaran jaringan. Apabila fungsi aktivasi yang dipakai bukan sigmoid biner, maka langkah 4 dan 5 harus diselesaikan. Demikian juga turunannya pada langkah 6 dan 7 .

Langkah 9 : Uji kondisi berhenti (akhir iterasi).

\section{Hasil DAN Pembahasan}

3.1. Variabel Penelitian. Dalam penelitian ini variabel yang digunakan yaitu suhu ratarata $\left({ }^{\circ} \mathrm{C}\right)$, curah hujan $(\mathrm{mm})$, jumlah hari hujan $(\mathrm{hh})$, kepadatan penduduk (km2), angka bebas jentik (\%) dan data kasus DBD di kota Ambon. Data-data yang digunakan adalah merupakan rekap data selama lima tahun terakhir dari tahun 2011-2015. Seluruh data yang telah terkumpul kemudian dipisahkan menjadi 2 bagian yaitu masukan dan keluaran. Data yang tergolong sebagai masukan secara berurut adalah sebagai berikut :

(1) Suhu udara rata-rata sebagai variabel $x_{1}$

(2) Curah hujan sebagai variabel $x_{2}$

(3) Jumlah hari hujan sebagai variabel $x_{3}$

(4) Kepadatan penduduk sebagai variabel $x_{4}$

(5) Angka bebas jentik sebagai variabel $x_{5}$

6. kasus DBD yang tergolong sebagai keluaran atau target yang diinginkan adalah sebagai variabel $y$.

Banyaknya data untuk penelitian ini sebanyak 82 data, dimana 62 data $(75,7 \%)$ digunakan untuk pelatihan dan 20 data $(24,3 \%)$ digunakan untuk pengujian. Keluaran atau target yang diinginkan dipresentasikan dengan bilangan binier yaitu: bebas kasus DBD (0) dan ada 
kasus DBD (1). Prosedur pemilihan pelatihan dan pengujian data dapat dilakukan secara acak, namun dalam penelitian ini data yang dipilih berdasarkan urutan tahun dan bulan.

3.2. Hasil Penelitian. Pada metode backpropagation, arsitektur sebuah jaringan akan menentukan keberhasilan target yang akan dicapai karena tidak semua permasalahan dapat diselesaikan dengan arsitektur yang sama. Gambar 7 menunjukkan bahwa arsitektur jaringan yang digunakan pada penulisan ini yaitu jaringan dengan multilayer yang menggunakan sebuah input dengan 5 neuron, satu hidden layer dan sebuah output dengan jumlah neuron output adalah satu.

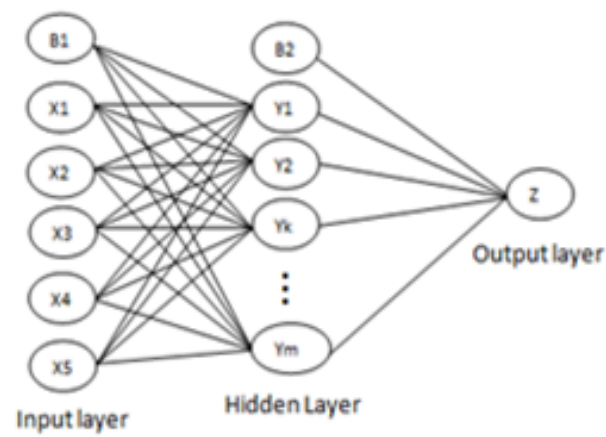

Gambar 7. Arsitektur JST untuk Sistem Penyebaran Penyakit DBD

Banyaknya neuron hidden layer pada penelitian ini ditentukan dengan cara trial and error, ini berarti bahwa hasil pembelajaran yang tercepat dan terbaik itulah yang akan menentukan banyaknya neuron hidden layer tersebut. Jumlah iterasi maksimum (epoch) yang digunakan adalah 5000 dan batas error (MSE) yang ditetapkan sebesar 0.01.

Tabel 1. Variasi Jumlah Neuron Untuk Satu Hidden Layer

\begin{tabular}{c|c|c|}
\hline Jumlah neuron & MSE & Waktu \\
\hline 5 & 0.0644 & $03: 19$ \\
\hline 10 & 0.0144 & $02: 48$ \\
\hline 15 & 0.0168 & $02: 50$ \\
\hline 20 & 0.0163 & 02.56 \\
\hline $\mathbf{2 5}$ & $\mathbf{0 . 0 1 0 0}$ & $\mathbf{0 2 : 2 8}$ \\
\hline 30 & 0.0100 & $02: 42$ \\
\hline
\end{tabular}

Pada Tabel 1 terlihat bahwa arsitektur jaringan dengan satu hiddeh layer memiliki kinerja yang cukup baik hal ini di tunjukan dengan nilai error (MSE) terkecil sebesar 0.0100 dengan waktu tercepat yaitu pada jumlah neuron sebanyak 25 neuron.

Berdasarkan tabel di atas, hasil terbaik pada proses pelatihan dan pengujian adalah pada saat (learning rate): 0.4 , dengan maksimum iterasi (epoch): 1005 dimana nilai MSE adalah 0.0099 dan tingkat keakuratan data $95.16 \%$ untuk tahap pelatihan dan untuk tahap pengujian $90 \%$.

Pada Gambar 9, akan ditunjukkan hasil analisa data dari alpha () 0.4 . Hasil perbandingan antara target $(\mathrm{o})$ dan output jaringan $\left(^{*}\right)$ untuk data pelatihan dapat diamati dengan cara memperhatikan penempatan posisi output jaringan $\left(^{*}\right)$. Jika output jaringan $\left(^{*}\right)$ menempati posisi yang sama atau jaraknya berdekatan dengan target (o) maka hasil analisa data tersebut dikatakan benar. Begitupula untuk data pengujian hasil analisa data tersebut dikatakan benar jika output jaringan $(+)$ menempati posisi yang sama atau jaraknya berdekatan dengan target (o) yang diharapkan. 
Tabel 2. Hasil Analisa Data Pelatihan dan Data Pengujian

\begin{tabular}{|c|c|c|c|c|c|c|c|c|}
\hline \multirow[b]{2}{*}{ No } & \multirow[b]{2}{*}{ A } & \multirow[b]{2}{*}{ MSE } & \multirow[b]{2}{*}{ Epoch } & \multirow[b]{2}{*}{ Waktu } & \multicolumn{2}{|c|}{ Hasil Pelatihan } & \multicolumn{2}{|c|}{ Hasil Pengujian } \\
\hline & & & & & $\begin{array}{c}\text { Data yang } \\
\text { dikenali }\end{array}$ & $\begin{array}{c}\text { Tingkat } \\
\text { keakuratan }\end{array}$ & $\begin{array}{c}\text { Data yang } \\
\text { dikenali }\end{array}$ & $\begin{array}{c}\text { Tingkat } \\
\text { keakuratan }\end{array}$ \\
\hline 1 & 0.1 & 0.0100 & 5000 & $02: 28$ & 59 & $95.16 \%$ & 17 & $85 \%$ \\
\hline 2 & 0.2 & 0.0099 & 4158 & $02: 27$ & 59 & $95.16 \%$ & 16 & $80 \%$ \\
\hline 3 & 0.3 & 0.0099 & 1996 & $00: 36$ & 59 & $95.16 \%$ & 16 & $80 \%$ \\
\hline 4 & 0.4 & 0.0099 & 1005 & $00: 34$ & 59 & $95.16 \%$ & 18 & $90 \%$ \\
\hline 5 & 0.5 & 0.0120 & 500 & $02: 58$ & 59 & $95.16 \%$ & 16 & $80 \%$ \\
\hline 6 & 0.6 & 0.0100 & 1720 & 01:05 & 59 & $95.16 \%$ & 14 & $70 \%$ \\
\hline 7 & 0.7 & 0.0099 & 2032 & $01: 17$ & 59 & $95.16 \%$ & 14 & $70 \%$ \\
\hline 8 & 0.8 & 0.0100 & 1382 & 01:06 & 59 & $95.16 \%$ & 18 & $95 \%$ \\
\hline 9 & 0.9 & 0.332 & 5000 & $03: 24$ & 53 & $85.5 \%$ & 13 & $65 \%$ \\
\hline
\end{tabular}

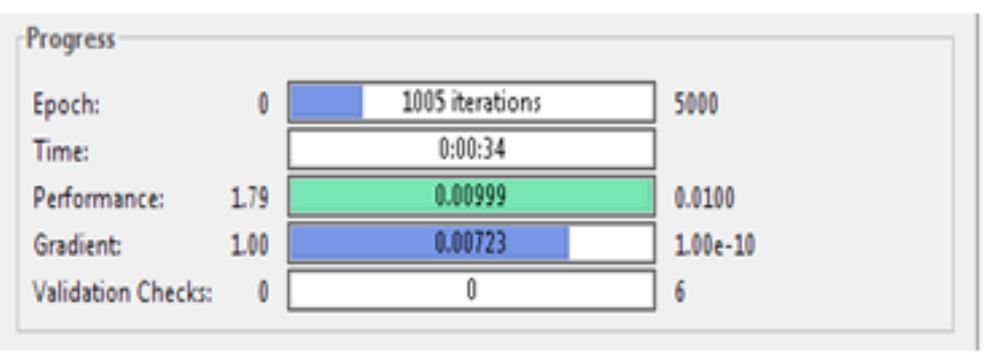

Gambar 8. Progress Neural Network Training

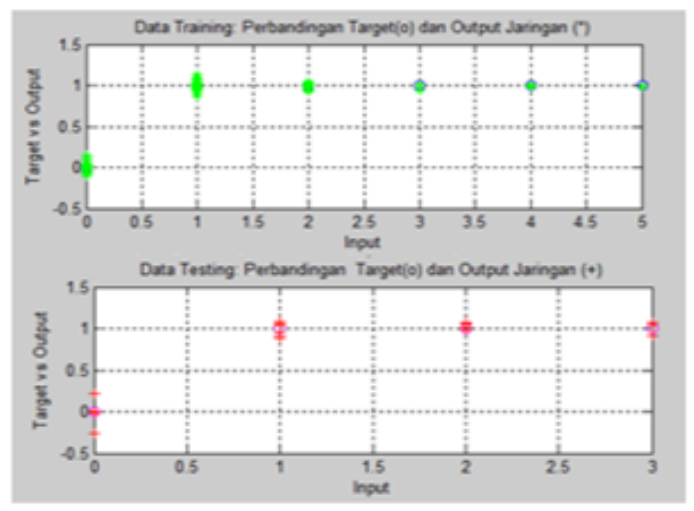

Gambar 9. Grafik Hasil Pelatihan dan Pengujian pada alpha 0.4

Setelah melakukan pengujian dan pelatihan, didapat keluaran/output prediksi seperti pada lampiran output. Di dalam pelatihan nilai bobot dan bias awal ditentukan dengan bilangan acak kecil agar mendapatkan eror yang minimum, agar hasil prediksi tidak berubahubah, karena jika tidak diberi batasan nilai bobot dan biasnya maka output jaringannya akan berubah-ubah setelah membentuk jaringan jika dilakukan pelatihan berulang kali meskipun dengan lapisan tersembunyi yang sama. Adapun hasil pengujian dan pelatihan didapat sebagai berikut: Berikut ini akan disajikan tabel perbandingan antara target yang diharapkan dan target hasil pengujian data.

Pada tabel 3 menunjukan bahwa dari 62 data pengujian, terdapat 59 data yang sesuai dengan target dengan tingkat keakuratan datanya sebesar 95.16

Dari Tabel 4 terdapat 2 data yang tidak sesuai dengan tingkat kesalahannya sebesar $10 \%$ sedangkan 18 data lainnya yang sesuai dengan target input dimana tingkat keakuratannya 
Tabel 3. Pengelompokkan Hasil Pelatihan

\begin{tabular}{|c|c|c|c|c|c|c|c|c|c|}
\hline No & $\begin{array}{c}\text { Target } \\
\text { Input }\end{array}$ & $\begin{array}{c}\text { Bobot } \\
\text { Output }\end{array}$ & Pengelompokan & Ket & No & $\begin{array}{c}\text { Target } \\
\text { Input }\end{array}$ & $\begin{array}{c}\text { Bobot } \\
\text { Output }\end{array}$ & Pengelompokan & Ket \\
\hline 1 & 1 & 0.9313 & 1 & Benar & 32 & 1 & 1.0160 & 1 & Benar \\
\hline 2 & 1 & 0.9654 & 1 & Benar & 33 & 1 & 0.9474 & 1 & Benar \\
\hline 3 & 1 & 1.0188 & 1 & Benar & 34 & 1 & 0.9735 & 1 & Benar \\
\hline 4 & 1 & 1.0025 & 1 & Benar & 35 & 1 & 1.0214 & 1 & Benar \\
\hline 5 & 1 & 0.9483 & 1 & Benar & 36 & 0 & 0.8236 & 1 & Salah \\
\hline 6 & 1 & 0.9881 & 1 & Benar & 37 & 0 & .0 .0155 & 0 & Benar \\
\hline 7 & 0 & 0.0314 & 0 & Benar & 38 & 0 & 0.0012 & 0 & Benar \\
\hline 8 & 1 & 0.9735 & 1 & Benar & 39 & 0 & 0.0188 & 0 & Benar \\
\hline 9 & 1 & 0.9990 & 1 & Benar & 40 & 0 & 0.0985 & 0 & Benar \\
\hline 10 & 1 & 0.9957 & 1 & Benar & 41 & 1 & 0.9147 & 1 & Benar \\
\hline 11 & 0 & 0.0082 & 0 & Benar & 42 & 1 & 0.9963 & 1 & Benar \\
\hline 12 & 1 & 0.9355 & 1 & Benar & 43 & 1 & 0.9647 & 1 & Benar \\
\hline 13 & 1 & 1.0938 & 1 & Benar & 44 & 1 & 0.9914 & 1 & Benar \\
\hline 14 & 1 & 1.0465 & 1 & Benar & 45 & 1 & 1.0276 & 1 & Benar \\
\hline 15 & 1 & 0.9712 & 1 & Benar & 46 & 1 & 1.1245 & 1 & Benar \\
\hline 16 & 1 & 0.9909 & 1 & Benar & 47 & 0 & 0.1497 & 0 & Benar \\
\hline 17 & 1 & 1.0505 & 1 & Benar & 48 & 0 & 0.0227 & 0 & Benar \\
\hline 18 & 0 & 0.0068 & 0 & Benar & 49 & 0 & 0.0411 & 0 & Benar \\
\hline 19 & 1 & 0.9839 & 1 & Benar & 50 & 1 & 0.9862 & 1 & Benar \\
\hline 20 & 1 & 1.0666 & 1 & Benar & 51 & 0 & 0.0053 & 0 & Benar \\
\hline 21 & 1 & 1.0066 & 1 & Benar & 51 & 0 & 0.0520 & 0 & Benar \\
\hline 22 & 1 & 0.8722 & 1 & Benar & 53 & 0 & 0.0321 & 0 & Benar \\
\hline 23 & 1 & 0.4935 & 0 & Salah & 54 & 1 & 0.9912 & 1 & Benar \\
\hline 24 & 0 & 0.0172 & 0 & Benar & 55 & 0 & 0.0118 & 0 & Benar \\
\hline 25 & 0 & 0.1175 & 0 & Benar & 56 & 0 & 0.0810 & 0 & Benar \\
\hline 26 & 1 & 1.0022 & 1 & Benar & 57 & 0 & 0.0111 & 0 & Benar \\
\hline 27 & 1 & 1.0107 & 1 & Benar & 58 & 1 & 1.0134 & 1 & Benar \\
\hline 28 & 1 & 1.0360 & 1 & Benar & 59 & 0 & 1.0069 & 1 & Salah \\
\hline 29 & 1 & 1.0471 & 1 & Benar & 60 & 0 & 0.0737 & 0 & Benar \\
\hline 30 & 1 & 0.9594 & 1 & Benar & 61 & 0 & 0.0277 & 0 & Benar \\
\hline 31 & 1 & 0.9477 & 1 & Benar & 62 & 1 & 0.9841 & 1 & Benar \\
\hline
\end{tabular}

Tabel 4. Pengelompokkan Hasil Pengujian

\begin{tabular}{|c|c|c|c|c|}
\hline No. & Target Input & Bobot Output & Pengelompokan & Ket \\
\hline 1 & 1 & 1.1628 & 1 & Benar \\
\hline 2 & 1 & 1.0233 & 1 & Benar \\
\hline 3 & 1 & 1.0219 & 1 & Benar \\
\hline 4 & 1 & 1.1055 & 1 & Benar \\
\hline 5 & 1 & 1.0717 & 1 & Benar \\
\hline 6 & 1 & 0.7589 & 1 & Benar \\
\hline 7 & 1 & 1.0232 & 1 & Benar \\
\hline 8 & 1 & 0.8601 & 1 & Benar \\
\hline 9 & 1 & 1.0060 & 1 & Benar \\
\hline 10 & 1 & 1.1376 & 1 & Benar \\
\hline 11 & 1 & -0.1958 & 0 & Salah \\
\hline 12 & 1 & 1.0057 & 1 & Benar \\
\hline 13 & 1 & 1.0214 & 1 & Benar \\
\hline 14 & 1 & 0.8653 & 1 & Benar \\
\hline 15 & 0 & 0.3648 & 0 & Benar \\
\hline 16 & 0 & -0.0554 & 0 & Benar \\
\hline 17 & 0 & -0.1461 & 0 & Benar \\
\hline 18 & 1 & 0.1804 & 0 & Salah \\
\hline
\end{tabular}

sebesar $90 \%$. Hal ini menunjukan bahwa untuk penyebaran penyakit DBD tidak dapat diukur secara keseluruhan hanya dengan menggunakan data jumlah kasus DBD saja tapi juga dapat menggunakan data lain yang berperan mempengaruhi penyebaran penyakit tersebut seperti faktor cuaca dan lainnya. 


\section{Simpulan}

Dari hasil penelitian, diperoleh arsitektur jaringan terbaik dari satu hidden layer dengan jumlah neuron sebanyak 25 neuron dan algoritma pelatihan terbaik yaitu dengan menggunakan learning rate sebesar 0,4 dengan MSE 0,0099. Dengan demikian, berdasarkan data yang dianalisis didapat disimpulkan bahwa Jaringan Saraf Tiruan metode backpropagation untuk penyebaran penyakit DBD di Kota Ambon memiliki tingkat keakuratan yang tinggi yaitu sebesar 90\%. Pengujian dengan Metode Backpropoagation ini tergantung pada pemilihan nilai $\alpha$ (learning rate) yang tepat, jika pengambilan data pengujian dilakukan untuk 20 data lainnya, maka tingkat keakuratan pengenalan pola bisa saja berubah namun tidak terlalu signifikan.

\section{DAFTAR Pustaka}

[1] Dinkes RI. 2010. Bulletin Jendela Epidemiologi. Jakarta. Diakses pada tanggal 15 Juni 2016 di http://www.depkes.go.id

[2] Dinkes Prov Maluku. 2015. Provil Kesehatan Provinsi Maluku Tahun 2014.

[3] Dipri A, A. 2009. Skripsi Pendeteksi Sistem Pengenalan Penyakit Jantung Dengan Metode Jaringan Syaraf Tiruan. Depok: Universitas Indonesia

[4] Hashim, Hasan Halib. 2005. Belajar Sendiri Dasar Dasar Pemograman Matlab Lengkap Disertai Teori Dan Aplikasinya. Yogyakarta: Gava Media

[5] Hermawan, Arief. 2006. Jaringan Syaraf Tiruan Teori dan Aplikasi. Yogyakarta: Andi.

[6] Hurasan, Siti Halimah. 2016. Skripsi Aplikasi Jaringan Saraf Tiruan Metode Backpropagation Untuk Mendeteksi Hama Penggerek Batang Dengan Mempertimbangkan Faktor Curah Hujan, Suhu, Kelembaban Dan Kecepatan Angin. Ambon: Universitas Pattimura

[7] Jatmiko W, dkk. 2011. Implementasi Berbagai Algoritma Neural Network dan Wavelet pada FPGA. Depok : Universitas Indonesia

[8] Jumarwanto, A. 2009. Aplikasi Jaringan Saraf Tiruan Backpropagation Untuk Memprediksi Penyakit THT Di Rumah Sakit Mardi Rahayu Kudus. Jurnal Teknik Elektro. Diakses pada tanggal 15 juni 2016

[9] Kemenkes RI. 2015. Artikel Demam Berdarah Biasanya Mulai Meningkat di Januari. Diakses pada tanggal 15 juni 2016 di http://www.depkes.go.id

[10] Kristanto,andri. 2004. Jaringan syaraf tiruan . Yogyakarta: andi

[11] Kusumadewi, sri 2004. Membangun Jaringan Syaraf Tiruan Menggunakan Matlab Dan Excel Link. Yogyakarta: Graham

[12] M. F. Andrijasa, Mistianingsih. 2010. Jaringan Syaraf Tiruan Untuk Memprediksi Jumlah Pengangguran di Privinsi Kalimantan Timur dengan Menggunakan Algoritma Pembelajaran Backpropagation, Jurnal Informatika Mulawarman.

[13] Muis, Saludin.2006. Teknik Jaringan Saraf Tiruan. Yogyakarta:

[14] Prasetyo, Eko. 2014. Data Mining: Mengolah Data Menjadi Informasi Menggunakan Matlab. Yogyakarta : Andi.

[15] Puspitaningrum, Diyah. 2006. Pengantar Jaringan Syaraf Tiruan. Yogyakarta: Andi.

[16] Puspitorini,Sukma. 2012. Arsitektur Jaringan Syaraf Tiruan. Diakses pada Tanggal 17 Oktober 2016.

[17] Siang, J. J., 2005. Jaringan Syaraf Tiruan dan Pemogramannya Menggunakan Matlab. Yogyakarta: Andi

[18] Sumardi, H.S. modul Artifical Intelligent. Pusat Pengembangan Bahan Ajar Universitas Widyagama Malang Jurusan Teknik Elektro. Diakses Tanggal 2 September 2016. 